\title{
Kaupapa Māori action research in a Whānau Ora collective: An exemplar of Māori evaluative practice and the findings
}

Maria Baker, Kataraina Pipi, and Terri Cassidy

Whānau Ora, introduced as a government initiative in Aotearoa New Zealand in 2010, was designed to support collaboration and effective service delivery by Māori non-government organisations. The aim of Whānau Ora is to improve heath and social outcomes for whānau. Action research was conducted to support this initiative, with action researchers walking alongside Whānau Ora collectives to support their collaborative planning, research, evaluation and reflection. This article examines the implementation of the evaluative component of kaupapa Māori (by Māori, for Māori, with Māori) action research with a Whānau Ora collective, Te Hau Āwhiowhio ō Otangarei. An integrated action-research approach based on kaupapa Māori principles supported methodological decisions. These decisions, in turn, informed the choice of evaluation methods used (e.g., wānanga, reflective hui, whānau interviews), and four of the methods chosen and the concomitant evaluative findings are described. It is concluded that the effectiveness of integrating action research with kaupapa Māori principles has provided a multi-method evaluation approach that works well for Māori communities. 
Ki te whai ao ... ki te ao mārama ... tihei mauri ora

The transitional state between darkness (the unknown) and light (understanding) transforms to the world of light and then to a sense of meaning, and a way of being

In 2009 the Minister for the Community and Voluntary Sector, the Hon Tariana Turia, established the Whānau Ora Taskforce on whānau-centred initiatives. The Taskforce developed a framework for a whānau-centred approach that would strengthen whānau wellbeing and development, and affirmed five foundations of effective whānau-centred service delivery: whānau, hapū and iwi leadership; strengths-based whānau engagement and action; whānau-centred design and delivery of services; active and responsive government; and funding (i.e., a relational approach to contracting with funding consistent with Whānau Ora) (Taskforce on Whānau-Centred Initiatives, 2010). In 2010, Whānau Ora was introduced as a government initiative designed to support Māori provider organisations and other services to collaborate to deliver effective whānau-centred services to individuals and whānau. Te Puni Kōkiri (the Ministry of Māori Affairs) selected 25 Whānau Ora collectives from across the country to participate in the first tranche of the Whānau Ora initiative. These collectives were charged with the transformation of their services to Māori, and the consequent implementation of a whānau-centred approach designed to deliver whānau ora (Māori family wellness).

\section{Te Hau Āwhiowhio ō Otangarei Whānau Ora Collective}

Te Hau Āwhiowhio ō Otangarei Whānau Ora Collective (the Collective) was one of those selected. The Collective is based in Otangarei, Northland, part of the Ngāpuhi iwi region, and is guided by the kawa and tikanga of Ngāpuhi. The work of the Collective is informed by a view that there are constant changes in this world that 
influence the circumstances of whānau today. These diverse circumstances are shaped by life factors, a person's growth and development, that person's environment (political, economic, and social), and by that person's whānau, hapū, and iwi.

The Collective was formed in 2010 and was initially made up of six independent organisations: five social service providers, including two that were Otangarei-based, and one local television station. In 2014 the Collective consolidated its focus to "mā Otangarei mō Otangarei-by Otangarei for Otangarei". This resulted in the merger of the Collective's two Otangarei-based providers-Otangarei Trust, a youth and social services provider, and Te Puāwaitanga ō Otangarei Healthcare Centre-into one provider named Te Hau Āwhiowhio o Otangarei Trust. This merger revitalised the concept of kāinga (a place of belonging and connection) and strengthened the Collective's vision and aspirations for the future for whānau in Otangarei. The Collective's metaphoric vision for the Otangarei community and whānau within it is to grow a forest (ngahere)_including a strong pūriri tree. The pūriri has a significant presence in the Otangarei community, and is reminiscent of the Ngāpuhi whakataukī "Ka kata ngā pūriri o Taiamai", which extends notions of strength and hospitality. In this forest each whānau is considered to be a tree, and growth is mā Otangarei, mō Otangarei. The Collective recognised that, to achieve and maintain whānau ora, a systemic framework was needed which enabled the identification of clear roles, responsibilities, and actions at whānau and community levels. Action researchers were seen as being able to support the development of this framework.

\section{Action research}

Action research was implemented by Te Puni Kōkiri to support the Whānau Ora initiative. Action researchers were tasked with walking alongside each Whānau Ora collective to support their collaborative 
planning, research, evaluation and reflection. There were five phases to the action research with Whānau Ora collectives: engage, plan, research, evaluate, and reflect. The engagement and planning phases gave action researchers and Whānau Ora collectives an opportunity to get to know each other and to co-design the research, evaluation, and reflection phases. It was anticipated that the research phase would then inform the delivery of services by Whānau Ora collectives, and that some part of this service delivery would subsequently be evaluated. The final phase was to allow action researchers to support Whānau Ora collectives to reflect on what they were learning about whānau-centred service delivery and whānau ora (Cram, 2011).

The Collective determined criteria for engaging action researchers that were based on previous experiences with researchers and evaluators. It was important to the Collective that the action researchers:

- had credibility in the research and evaluation sector, and with the Collective

- would work with the Collective to ensure the research and evaluation was "done with them, not to them"

- would be able to give critical reflection and feedback

- were Māori, preferably with tribal affiliations to Te Tai Tokerau

- understood the Māori worldview

- understood and could work with the nuances of the community and Māori organisations and

- understood clinical and community work with whānau.

From these criteria the Collective proactively identified and recruited two action researchers. Once these action researchers agreed in principle to be involved, the Collective negotiated their appointment with the funder. This process was somewhat outside the norm as most collectives were given the opportunity to choose from a list of action 
researchers identified by the funder.

During 2012-2014, a kaupapa Māori (by Māori, for Māori, with Māori) action-research programme was conducted in partnership with the Collective. The focus of this article is on phase 4, evaluation, of the action research undertaken with the Collective. The following high-level questions directed the inquiry.

- What are the needs and aspirations of whānau?

- What are the motivators and barriers to whānau achieving their goals?

- In what ways do whānau see that providers can support them to achieve their aspirations?

- How and in what ways are whānau better off?

- What difference has the Collective made?

- How has Te Rōpū Rangahau community research model increased workforce capability and capacity?

The action researchers made methodological and method decisions in close collaboration with the Collective. A key feature of these decisions was the affirmation and validation of Māori ways of knowing and being within a Whānau Ora context; hence the implementation of kaupapa Māori action research.

\section{Kaupapa Māori action research}

Action research is a powerful tool for change and improvement in services for Maori when it is utilised appropriately within a Māori context (Kerr, Penney, Moewaka Barnes, \& McCreanor, 2010). The overarching purpose of action research within the Whānau Ora initiative was to support Whānau Ora collectives' implementation of successful whānau-centred service delivery, and to evidence their facilitation of whānau ora outcomes (Cram, 2011). Action research provided collectives with the ability to systematically reflect on 
their work and to conduct a deep inquiry into the transformation of services and professional practice that was expected within the Whānau Ora initiative. As a means to evaluate whānau-centred service delivery, action research was a community-led process with a transformative focus (Mertens, 2009). A driving motivator was the provision of a means to increase knowledge about the delivery of Whānau Ora services that was responsive to the providers within the Collective and to the whānau they served.

The recognition of a Māori worldview, or ways of being and practicing, was an important principle underpinning the action research undertaken with the Collective. Any research or evaluation with the Collective needed to be infused with a uniquely Māori way of looking at the Collective's world, their leadership, and their learning processes (Smith, 1999). Engagement by the Collective and the action researchers with kaupapa Māori action research ensured the centrality of Māori cultural epistemology; that is, an implicit understanding that Māori have a distinct way of viewing and interpreting the world (Cram, Kennedy, Paipa, Pipi, \& Wehipeihana, 2015; Nepe, 1991). Māori evaluators have combined kaupapa Māori and action research previously to conduct bespoke assessments of the implementation and outcomes of programmes. Such evaluations have had a deliberate emphasis on empowerment and Māori development (Moewaka Barnes, 2000).

The integration of action research with kaupapa Māori recognised that the tikanga values of the Collective were central to its transformation, and this in turn supported methodological decisions. It was important to use tikanga Māori approaches in the engagement activities during this action research. The action researchers followed the tikanga as determined by the Collective, including using karakia, mihimihi, whakawhitiwhiti whakaaro (facilitated discussion), kōrero āwhina (affirming and validating whānau and staff approaches) and 
tautohetohe (debate) as necessary. In addition, the Collective’s Māori values of tika, pono, aroha, kotahitanga, and rangatiratanga were used as a filter in the sense-making process throughout all research activities. It was also imperative that any methods used were aligned with the core foundational principles of the Collective so that any research or evaluation conducted under the auspices of the action research contributed to positive change for Māori (Smith, G., 2005).

\section{Methods}

The methods used in the kaupapa Māori action research included: logic model and rubric development; documentation review; case studies; review and analysis of whānau PATH plans (Pipi, 2010); focus-groups; interviews; group reflective hui; participant observation; iterative discussions; and comparative coding (Pipi \& Baker, 2014). There were also in-depth wānanga reflecting on the development of the service model and framework. Using these various methods data was gathered from 119 people, including managers, review board members, kaiārahi (navigators), Te Rōpū Rangahau (community research team) members, provider staff, and whānau members.

Four of the evaluation methods used in Phase 4 of the kaupapa Māori action research are described next: whānau interviews; logic model and rubric development; wānanga; and reflective hui. These methods informed the development of an emerging Whānau Ora framework that showcases the importance of relationships, and the transformation of the service providers as well as whānau.

\section{Whānau interviews}

Twelve face-to-face whānau interviews were held to seek feedback using participatory and engaging approaches to support conversations. Whānau feedback during an interview was depicted in pictorial form 
(symbols and pictures) as they spoke and this helped them feel comfortable about sharing their insights (see Figure 1). Whānau could literally see the story they were sharing as it unfolded, and used this visual representation to make meaning of their experiences. This method worked well in individual and group situations, as often the graphic would prompt further insight, discussion and affirmation for whānau. Whānau also became aware of the positive steps they had taken.

It's not until you see what you've done that you realise how far you've come. (Whānau)

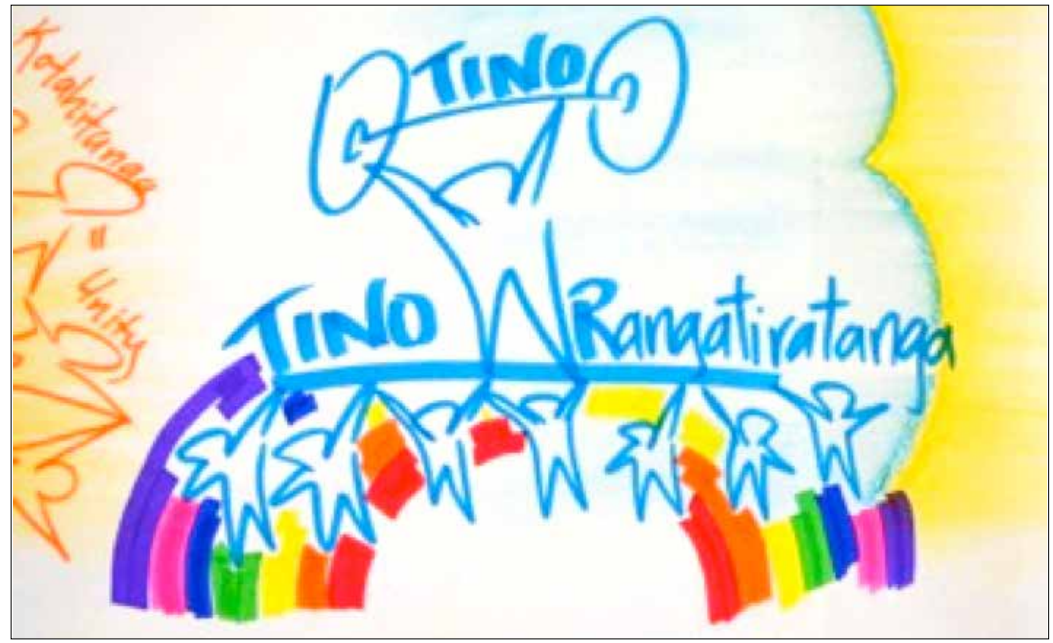

Figure 1. Graphic depicting building of whānau capacity (Artist: Maraea Pipi-Takoko)

The whānau interviews provided good evidence that whānau engaging with the Collective were achieving outcomes aligned to the high-level Whānau Ora goals and whānau outcomes. These included: being self-managing; creating healthier lifestyles; increasing participation in the community; having improved resilience; and improving participation in te ao Māori. An example was the Whānau Ora journey for Rangi ${ }^{1}$, who moved from a state of depression to being

1 Pseudonyms are used for anonymity in this article. 
highly motivated to change. Rangi's depression resulted from a series of events including relationship separation, loss of parental rights through Child, Youth and Family services, substance use, depression, and isolation. Following 3 years of ongoing contact and guidance by kaimahi, counselling, budgeting advice, assistance with gaining access to her children, and deliberate facilitation to connect with her Māori cultural heritage, Rangi was no longer using substances or antidepressants, had improved cultural belonging, was highly motivated, and had stronger relationships with her whānau and others. The action researchers concluded that semistructured whānau interviews that focused on the most significant change for whānau proved to be positive, and that creative approaches in an interview helped the flow of conversation with whānau.

Whānau interviews identified nine key factors for whānau transformation:

- critical intervention opportunities

- women as key influencers of whānau change

- different engagement pathways for men

- the importance of location of services

- the motivational effect of sharing personal experiences

- empowerment through financial literacy

- family violence as an endemic issue

- the value of Māori healing processes

- the complexity of the whānau ora journey.

The Collective was able to reflect on each factor. This reflection supported a deeper level of understanding abut the issues impacting on whānau and the types of services and approaches that would best support them. 


\section{Logic model and rubric development}

From the outset of this work, the action researchers detected a recurring theme that quality relationships are the key to successful whānau engagement, effective whānau-centred practice, and collaborative approaches to service delivery. The action researchers therefore worked alongside an external evaluator to undertake a value of relationships study. A set of inquiry questions was determined, a logic model (see Figure 2) and rubric (Davidson, 2005) were developed, and an approach was designed for gathering information to inform the study.

The logic model and rubric helped the action researchers investigate relationships that aid transformation when they interviewed whānau, staff, the steering group, and the review board. The logic-model development enabled reflective discussion on the various criteria that were important at each level, and for whom. Developing the rubric enabled the researchers to explore the various types and levels of relationships across the Collective. Rubric development also helped to consolidate thinking around the questions to be asked in forthcoming interviews, and became the Collective's framework for assessing the value of relationships (see Table 1). The inquiry questions focused both on understanding how to nurture good relationships and on what was gained from investment in relationships. The evaluation was qualitative and involved discussions with a range of Collective stakeholders, including whānau, provider staff, and governance representatives. 
When we have good relationships...

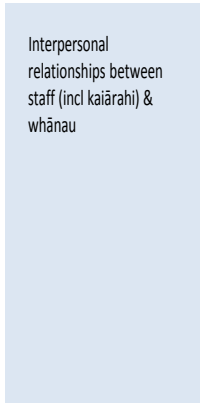

Interpersonal relationships between provider staff

Interorganisational relationships

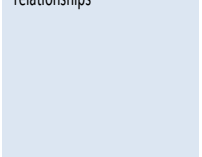

Sector relationships (wider system: funders, Whānau Ora, health \& social services, Māori, iwi)

Assumptions: strengths-based, non-punitive

Empathy

Openness/honesty that reflect these features... $\quad$ positive steps occur...

\begin{tabular}{|l|l}
\hline Genuineness & Whānau: \\
& Trust in the service \\
& Have confidence in the service \\
& Buy into the messages \\
& Are motivated \\
& Staff: \\
& Understand whānau dynamics \\
& and realities \\
& Can take whānau anywhere \\
Reciprocity & It also: \\
& Speeds up the process of change \\
& Provides quality information \\
& Builds two way relationship \\
& Develops deeper level of sharing \\
\hline Tika &
\end{tabular}

Reflective and deliberate

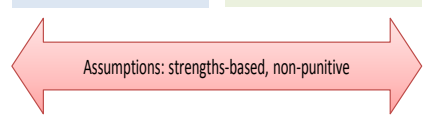

which leads to better results... $\quad$ and improved whānau outcomes.

Mahi ā-whānau

Responsibility

Accountability

Strong foundation

practice

Knowledge

Affirmation of cultural identity

More willingness to share

resources \& knowledge

Collaboration

Pooling of resources

Cross referrals

More integrated service

delivery

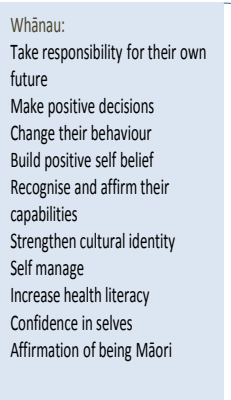

Improved access to appropriate supports

Better access to more services

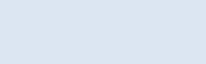

More seamless service pathways

Funder better understands operational aspects of service delivery

Speeds up contracting

processes

Better evidence base
More sustainable outcomes

Appropriate levels of resourcing

Appropriate supports provided

Integrated service delivery

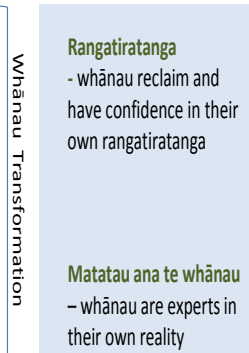

Tū pakari

- whānau are thriving and healthy

Mana motuhake

- whānau are economically secure and contributing to community

Figure 2. Value of Relationships Logic Model 
Table 1. Framework for assessing quality of relationships

\begin{tabular}{|c|c|c|c|c|}
\hline $\begin{array}{l}\text { Quality of } \\
\text { relationships }\end{array}$ & $\begin{array}{l}\text { Inter-personal } \\
\text { relationships } \\
\text { between staff } \\
\text { (incl kaiārahi) \& } \\
\text { whānau }\end{array}$ & $\begin{array}{l}\text { Inter-personal } \\
\text { relationships } \\
\text { between } \\
\text { provider staff }\end{array}$ & $\begin{array}{l}\text { Inter- } \\
\text { organisational } \\
\text { relationships }\end{array}$ & $\begin{array}{l}\text { Sector } \\
\text { relationships } \\
\text { (wider system: } \\
\text { funders, } \\
\text { Whānau Ora, } \\
\text { Health \& Social } \\
\text { Services, Māori, } \\
\text { iwi) }\end{array}$ \\
\hline $\begin{array}{l}\text { Tino pai } \\
\text { rawa atu }\end{array}$ & $\begin{array}{l}\text { Relationships are } \\
\text { reciprocal; whānau } \\
\text { are responsive } \\
\text { to staff, and vice } \\
\text { versa. } \\
\text { The relationship } \\
\text { is conducive to } \\
\text { whānau driving } \\
\text { their own self- } \\
\text { actualisation. } \\
\text { The relationship } \\
\text { is supportive } \\
\text { of whānau } \\
\text { maintaining their } \\
\text { wellness. }\end{array}$ & $\begin{array}{l}\text { Relationships } \\
\text { are reciprocal; } \\
\text { staff are } \\
\text { responsible and } \\
\text { accountable to } \\
\text { each other. } \\
\text { Relationships } \\
\text { are centred on } \\
\text { the interests } \\
\text { of whānau } \\
\text { wellbeing. } \\
\text { Relationships } \\
\text { consistently } \\
\text { reflect and } \\
\text { uphold the } \\
\text { kaupapa of the } \\
\text { Collective. }\end{array}$ & $\begin{array}{l}\text { Relationships } \\
\text { are reciprocal; } \\
\text { providers are } \\
\text { responsible and } \\
\text { accountable to } \\
\text { each other. } \\
\text { Relationships } \\
\text { are centred on } \\
\text { the interests of } \\
\text { whānau wellbeing. } \\
\text { Relationships } \\
\text { consistently reflect } \\
\text { and uphold the } \\
\text { kaupapa of the } \\
\text { Collective. }\end{array}$ & $\begin{array}{l}\text { Relationships } \\
\text { are reciprocal; } \\
\text { funders and } \\
\text { sector are } \\
\text { responsible and } \\
\text { accountable to } \\
\text { each other. } \\
\text { Relationships } \\
\text { are centred on } \\
\text { the interests of } \\
\text { whānau/hapū/ } \\
\text { iwi wellbeing. } \\
\text { Relationships } \\
\text { consistently } \\
\text { reflect and } \\
\text { uphold the } \\
\text { kaupapa of } \\
\text { Whānau Ora. }\end{array}$ \\
\hline Tino pai & $\begin{array}{l}\text { Relationships are } \\
\text { mana-enhancing. } \\
\text { They support } \\
\text { whānau feeling } \\
\text { affirmed and } \\
\text { validated, building } \\
\text { confidence and } \\
\text { pride. }\end{array}$ & $\begin{array}{l}\text { Relationships } \\
\text { are mana- } \\
\text { enhancing. They } \\
\text { support staff } \\
\text { feeling affirmed } \\
\text { and validated, } \\
\text { building } \\
\text { confidence and } \\
\text { pride. }\end{array}$ & $\begin{array}{l}\text { Relationships are } \\
\text { mana-enhancing. } \\
\text { They provide a } \\
\text { firm foundation for } \\
\text { leaders and staff } \\
\text { to create and seize } \\
\text { opportunities. }\end{array}$ & $\begin{array}{l}\text { Relationships } \\
\text { are mana- } \\
\text { enhancing. } \\
\text { They provide a } \\
\text { firm foundation } \\
\text { for leaders and } \\
\text { staff to create } \\
\text { and seize } \\
\text { opportunities. }\end{array}$ \\
\hline Pai & $\begin{array}{l}\text { Relationships are } \\
\text { meaningful and } \\
\text { purposeful. They } \\
\text { are also trusting, } \\
\text { tika, pono, aroha, } \\
\text { genuine, honest, } \\
\text { open. }\end{array}$ & $\begin{array}{l}\text { Relationships } \\
\text { are meaningful } \\
\text { and purposeful. } \\
\text { They are also } \\
\text { trusting, tika, } \\
\text { pono, aroha, } \\
\text { genuine, } \\
\text { honest, open. }\end{array}$ & $\begin{array}{l}\text { Relationships are } \\
\text { meaningful and } \\
\text { purposeful. They } \\
\text { are also trusting, } \\
\text { tika, pono, aroha, } \\
\text { genuine, honest, } \\
\text { open. }\end{array}$ & $\begin{array}{l}\text { Relationships are } \\
\text { meaningful and } \\
\text { purposeful. They } \\
\text { are also trusting, } \\
\text { tika, pono, aroha, } \\
\text { genuine, honest, } \\
\text { open. }\end{array}$ \\
\hline
\end{tabular}




\begin{tabular}{|c|c|c|c|c|}
\hline $\begin{array}{l}\text { Āhua pai te } \\
\text { haere }\end{array}$ & $\begin{array}{l}\text { Whānau and staff/ } \\
\text { kaiārahi have built } \\
\text { a relationship, } \\
\text { effective enough } \\
\text { to start identifying } \\
\text { underlying issues. } \\
\text { Relationships are } \\
\text { respectful and } \\
\text { professional. }\end{array}$ & $\begin{array}{l}\text { Staff/kaiārahi } \\
\text { have respectful } \\
\text { and professional } \\
\text { relationships } \\
\text { with one } \\
\text { another, } \\
\text { effective } \\
\text { enough to } \\
\text { provide a } \\
\text { professional } \\
\text { service to } \\
\text { whānau. }\end{array}$ & $\begin{array}{l}\text { Relationships } \\
\text { between providers } \\
\text { are professional } \\
\text { and respectful, } \\
\text { effective enough } \\
\text { to present a } \\
\text { united Collective } \\
\text { to whānau, even } \\
\text { if some tensions } \\
\text { are being resolved } \\
\text { behind the scenes. }\end{array}$ & $\begin{array}{l}\text { Relationships are } \\
\text { professional and } \\
\text { respectful. }\end{array}$ \\
\hline Kore pai & $\begin{array}{l}\text { Relationships that } \\
\text { just tick the box, } \\
\text { will get you by, but } \\
\text { not good enough } \\
\text { to achieve real } \\
\text { engagement. }\end{array}$ & $\begin{array}{l}\text { Staff/kaiārahi } \\
\text { interpersonal } \\
\text { relationships } \\
\text { are not good } \\
\text { enough to } \\
\text { provide a } \\
\text { professional } \\
\text { service to } \\
\text { whānau (for } \\
\text { example, } \\
\text { tensions } \\
\text { between staff } \\
\text { are evident to } \\
\text { whānau visiting } \\
\text { the service). }\end{array}$ & $\begin{array}{l}\text { Providers are } \\
\text { not on the same } \\
\text { wavelength in } \\
\text { terms of kaupapa. } \\
\text { They are looking } \\
\text { after their own } \\
\text { interests first, } \\
\text { instead of the } \\
\text { interests of } \\
\text { whānau. As a } \\
\text { result, whānau } \\
\text { receive mixed } \\
\text { or contradictory } \\
\text { messages. }\end{array}$ & $\begin{array}{l}\text { Relationships } \\
\text { between funders } \\
\text { and the sector } \\
\text { (and/or within } \\
\text { the sector) are } \\
\text { unprofessional or } \\
\text { disrespectful. }\end{array}$ \\
\hline
\end{tabular}

The findings reiterated the importance of relationships as a key driver for whānau and provider transformation. The features of good relationships within the Collective's context were: reciprocity, tika (correct, right), pono (honesty, truth), aroha (compassion, affection), rapport, consideration, and empathy. The Collective had invested time, money, effort, commitment, faith, and hope in building and maintaining good relationships. By investing in relationships, the providers gained: extended networks; increased knowledge and understanding of other services; more cross-agency collaboration; affirmation and validation of the Collective's kaupapa; better understanding of what works for whānau; improved capacity and capability 
to support whānau, more streamlined service delivery; and an ability to better meet the needs of whānau. Whānau are experiencing trusting, meaningful, and purposeful relationships, and this has motivated them to take ownership of their own futures by planning, setting goals, identifying aspirations, and working towards these independently or with support from kaiārahi (Pipi \& Baker, 2014).

The action researchers concluded that the use of the logic model and rubrics in the value of relationships evaluation led to clarity around the nature of relationships and their contribution to outcomes. The study itself provided evidence of the recurring theme of the quality of relationships and enabled discussion about how the principle of whanaungatanga is embedded in Māori relationships. In addition, the value of relationships logic model (Figure 2) and the framework for assessing quality of relationships (Table 1) are both resources the Collective aims to continually reflect on.

\section{Wānanga}

Wānanga were held to explore in-depth, within a Māori worldview, key aspects of the action research. Staff and the Review Board came together to share and learn about how they used the organisational values in their practice. Steering group and Review Board members came together to wānanga about Ngāpuhi leadership. Outcomes of the wānanga included the emerging Whānau Ora framework and the surfacing of the Collective's kaiārahi (navigator) approach.

\section{Emerging Whānau Ora framework}

The emerging framework acknowledges that individuals, whānau and providers move along a transformation continuum. Still in development stage, the Collective hopes to be able to use it as a guide to understanding their work and as a basis for making decisions about their approach (see Table 2). 
Table 2. Emerging Whānau Ora framework

\begin{tabular}{|c|c|c|c|}
\hline \multirow{3}{*}{ States of being } & Te Whai Ao & Ki Te Ao Mārama & Tihei Mauri Ora! \\
\hline & $\begin{array}{l}\text { To the glimmer of } \\
\text { dawn }\end{array}$ & $\begin{array}{l}\text { To the bright light of } \\
\text { day }\end{array}$ & There is life \\
\hline & Transaction & Transition & Transformation \\
\hline Process & $\begin{array}{l}\text { An exchange of goods, } \\
\text { services, or funds }\end{array}$ & $\begin{array}{l}\text { Passage from one state, } \\
\text { stage, place to another }\end{array}$ & $\begin{array}{l}\text { To change (often radically) in } \\
\text { form, appearance, structure, } \\
\text { condition, nature or character }\end{array}$ \\
\hline Role & Storm breaker & Dream maker & Authenticator \\
\hline Responsibility & Engage \& Stop Chaos & $\begin{array}{l}\text { Advocate \& Promote } \\
\text { possibilities }\end{array}$ & Nurture \& Affirm actualisation \\
\hline Accountability & Satisfy need & $\begin{array}{l}\text { Rejuvenate hope \& } \\
\text { possibilities }\end{array}$ & Positive outcomes \\
\hline Outcomes & You Vision / Me Vision & Shared Vision & Our Vision \\
\hline
\end{tabular}

The emerging Whānau Ora framework acknowledges that individuals, whānau, and providers move along a transformation continuum. They transition from an initial state of working in a transactional way (where there is an exchange of good and services in response to needs), to a transitional stage (where there is a readiness to change with hope), through to a transformation (where changes start to occur, and individuals and whānau action their plans, affirm their aspirations and see positive change occurring). The Collective's Whānau Ora framework seeks to integrate understanding about different states of being, service processes and practices, roles and responsibilities for accountability and the expected outcomes for whānau. The framework builds on the assumption that, to achieve and maintain whānau ora, the sum of the whole is greater than the individual parts.

\section{Kaiārahi (navigator) approach}

A kaiārahi (navigator) case study was developed to describe the navigational approach being used by kaiārahi to support understanding about how they worked with whānau. This case study was an 
exemplar of the navigation approach taken by one kaiārahi within the Collective and outlined the different stages of engagement when supporting whānau in their transformational journey. This also provided evidence of the value of the approach to whānau. Figure 3 illustrates the navigational approach and includes factors of success as derived from kaiārahi and whānau feedback. These include: care for whānau, encourage them, follow through on promises to them, motivate them and believe in them.
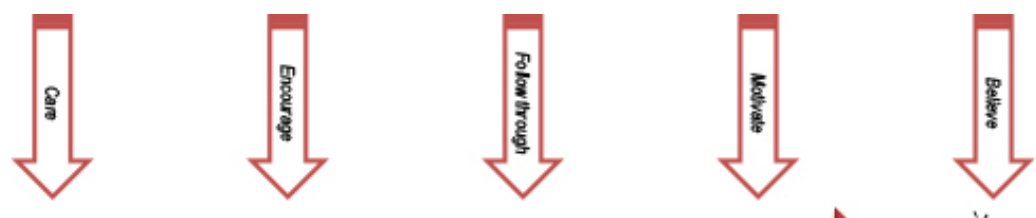

\section{Support whānau to achieve their aspirations}

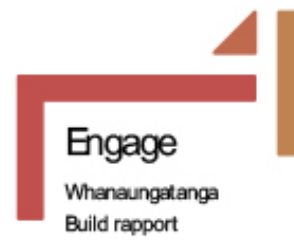

Navigate

Guide

Seek out supports

Provide advice and information

Whãnau planning

Help whänau get to

places

Support whãnau to

reflect on their

situation

Seek supervision

when necessary

Figure 3. The navigational approach 
Identifying and mapping the navigational approach in a diagrammatic form was useful for the kaiārahi reflecting on her practice. It also helped inform the development of the emerging Whānau Ora framework. It is clear that the ways in which kaiārahi invest in relationships with whānau has led to whānau transformation; that is, successful whānau who are working together and using the resources available to them. These gains were evidenced in three whānau case studies that illustrated the value of relationships in the context of the Whānau Ora journey. Overall, the action research highlighted the important role of kaiārahi in building quality relationships with whānau, and recognised that kaiārahi provide an important gateway for whānau to access services.

The action researchers concluded that wānanga supported in-depth thinking and discussion in a Māori context about significant Whānau Ora developments. The wānanga also reaffirmed and validated the value of being Māori and doing things in a Māori way, and were an ideal method for learning and reflection about the Collective's values.

\section{Reflective hui}

A series of planned reflective hui occurred regularly throughout Phase 3. These were deliberate in further socialising Whānau Ora as part of the key outcomes of the Collective. Staff came together for two one-day reflective hui to hear about and discuss the findings from the action research. The action researchers facilitated a range of group-based processes to encourage information sharing and opportunities for learning and reflection, and to elicit different perspectives and analyses of the data to hand. The outcomes of these hui included:

- whanaungatanga

- new information and the sharing of ideas

- clarity of purpose, mission and vision of the Collective 
- knowledge and skills necessary to understand their roles in the scheme of the Collective

- agreement, understanding and critical reflection about the findings of the action research

- identification of areas for improvement

- group ownership (e.g. the more people who understood the situation and how it related to the aspirations of whānau and service delivery, the more it motivated kaimahi to invest in making changes happen) (Baker \& Pipi, 2013).

A reflective hui with whānau who participated in a previous project using Photovoice as an evaluation method was held to present back the findings of this project and consult with whānau on the proposed service model. The Photovoice project was completed by 10 whānau, where they took photos to represent what Whānau Ora meant to them. Whānau shared their stories of the photos with researchers. The key themes from these whānau photos and stories provided direction for the Collective to develop a proposed service model framework to achieve the aspirations of whānau. The outcomes of this reflective hui with whānau were:

- whanaungatanga

- validation and affirmation of whānau contribution to the Photovoice project

- engagement with whānau and the Collective

- confirmation of the proposed service model and its principles.

The action researchers concluded that reflective hui provided regular face-to-face forums for discussions and updates on action research findings. The Kaiārahi found regular facilitated reflective discussions in hui to be valuable. In addition, reflective hui provided a forum for whānau to have a voice in the development of service models. 


\section{Discussion}

This article has provided a very broad description of the implementation of selected evaluation methods within the context of kaupapa Māori action research with a Whānau Ora collective. The process of doing this reiterated the importance of kaupapa; namely, that the action researchers needed to understand how kaupapa developed and influenced service delivery, workforce development, and leadership. Two high-level key lessons included:

- The importance of bringing to the forefront the value of being Māori.

- For relationships, it was acceptable to let them go if they were not working; that is, to acknowledge that relationships run their course, where these may no longer be needed or required when the value of the relationship is limited or is not there any longer.

The Collective believed that Whānau Ora was a destination and a journey and there were many unexpected things that occurred along the way that built knowledge. Two key lessons were:

- Moving into Whānau Ora land from provider land meant a spiritual, mental, and emotional connection with the whole kaupapa. "Whānau Ora was not an opportunity to put your toe in the water, you had to jump in and have faith" (quote from kaiwhakarite, 2015).

- There was a divide between the Whānau Ora Taskforce intention and how this was able to be enacted by Te Puni Kōkiri and the Collective. Bridging this divide required an understanding of the policy and provider environment and of grassroots whānau realities.

For the Collective, kaupapa drove everything they did and it was an expectation that they would stay on the kaupapa to achieve positive 
outcomes for whānau. However this was constrained by fiscal and political restrictions. In the bigger scheme of things there was a realisation of what really that mattered. Two key lessons were:

- Whānau Ora was about legacy making and legacy leaving and the Collective was operating at the intersection of these.

- Getting high-quality sustainable outcomes for whānau requires a systemic approach.

The Collective and the action researchers hoped that learning from kaupapa Māori action research would result in the following outcomes:

- Government would be better informed about the impact of Whānau Ora policy and funding decisions.

- Providers would be informed about service delivery, funding, and planning decisions.

- Whānau would be able to affirm, protect, and grow what mattered to them for their whānau ora journey.

- Evaluators and researchers would be inspired by kaupapa Māori approaches, while working to develop and build the knowledge and capacity of Māori providers.

The Whānau Ora framework, the value of relationships study, and findings from the navigational approach were three of the various outcomes for this Collective. The action research found various levels of change within both the providers and the whānau as a result of the Collective's activities. The different levels of transformation included individual, service provider, and Collective gains. In conclusion, the action research assisted the Collective to:

- critically reflect on the value of relationships, whānau and service provider transformation

- affirm and validate their Māori ways of knowing and being as 
significant to supporting positive whānau outcomes

- develop tools and frameworks to support their future aspirations for whānau ora.

Te piki ō te ora, tērā te tupu ō te rākau

With improved wellbeing, the tree will grow

\section{Glossary}

ao to dawn, bright, world

Aotearoa New Zealand

aroha compassion, affection

hapū kinship group, subtribe

iwi extended kinship group, tribe-often refers to a large group of people descended from a common ancestor and associated with

a distinct territory

kaiārahi navigator

kaimahi staff, worker

kaiwhakarite Whānau Ora programme manager

kaiwhakahaere operations manager

kaupapa purpose, aim, reason

kaupapa Māori Māori paradigm, ideology

kawa protocol

ki to, into, towards, on to, upon

kōrero āwhina affirming feedback

kotahitanga unity

mā by

Māori indigenous person of Aotearoa/New Zealand

mārama be clear, light (not dark), easy to understand mō for

Ngāpuhi Northland tribe in Aotearoa/New Zealand 
ngahere forest

Pono honesty, truth

poutama the stepped pattern, symbolising various levels of learning pūriri native tree

rākau tree

rangatahi adolescent

rangatiratanga self-determination, autonomy

takarangi shortened term for Takarangi Competency Framework-a

framework for kaimahi to validate their cultural competency level tauparapara incantation to begin a speech

tautohetohe debate

te the

Te Rōpū Rangahau community research team

Te Tai Tokerau Northland region in Aotearoa/New Zealand tihei mauri ora sneeze of life, call to claim the right to speak tika moral, correct, right

tikanga correct procedure, custom, lore, practice-the customary system of values and practices that have developed over time and are deeply embedded in the social context

tuakana/teina older/younger-More/less experienced

wānanga learning event

whai to follow, chase, pursue, look for

whakawhitiwhiti whakaaro facilitated discussion

whānau family

whanaungatanga relationships, kinship, sense of family connection whānau ora family wellbeing, wellness 


\section{References}

Baker, M., \& Pipi, K. (2013). Te Hau Āwhiowhio o Otangarei, action research report 1. Report presented to Te Puni Kōkiri.

Baker, M., Pipi, K. (2014). Action research report 2. Report presented to Te Puni Kōkiri.

Cram, F. (2011). Whānau Ora \& action research. Paper presented to Te Puni Kōkiri. Auckland: Katoa Ltd.

Cram, F., Kennedy, V., Paipa, K., Pipi, K., \& Wehipeihana, N. (2015). Being culturally responsive through kaupapa Māori evaluation. In S. Hood, R. Hopson, \& H. Frierson (Eds.), Continuing the journey to reposition culture and cultural context in evaluation theory and practice (pp. 289-311). Charlotte, NC: Information Age Publishing.

Davidson, E. J. (2005). Evaluation methodology basics: The nuts and bolts of sound evaluation. Thousand Oaks, CA: Sage.

Kerr, S., Penney, L., Moewaka Barnes, H., \& McCreanor, T. (2010). Kaupapa Māori action research to improve heart disease services in Aotearoa, New Zealand. Ethnicity \& health, 15(1), 15-31. http://dx.doi.org/10.1080/13557850903374476

Mertens, D. M. (2009). Transformative research and evaluation. New York: Guilford Press.

Moewaka-Barnes, H. (2000). Kaupapa Māori: Explaining the ordinary. Pacific Health Dialog, 7(1), 13-16.

Moss M., Smith, R., Spee, K., \& King, J. (2013). Evaluation of PATH facilitation training and PATH whänau planning. Auckland: Julian King \& Associates.

Nepe, T. M. (1991). Te toi huarewa: Kaupapa Mãori, an educational intervention system. Unpublished master's thesis, The University of Auckland.

Pipi, K. (2010). The PATH planning tool and its potential for whānau research. MAI Review, 3. 
Pipi, K., \& Baker., M. (2014). Action research 3 (phase 5) report. Report presented to Te Puni Kōkiri. Takitini Whānau Ora Action Research Collective.

Smith, G. H. (1995). Whakaoho whānau: new formations of whānau as an innovative intervention into Māori cultural and educational crises. He Pukenga Korero, 1(1), 18-36.

Smith, L. T. (1999). Decolonising methodologies: Research and indigenous peoples. Dunedin: University of Otago Press.

Statistics New Zealand (2014). Quick stats-Ōtangarei.

Retrieved from http://www.stats.govt.nz/Census/2013-census/ profile-and-summary-reports/quickstats-about-a-place. aspx?request_value $=13132 \&$ tabname $=$ Business

Taskforce on Whānau-Centred Initiatives. (2010). Report of the Taskforce on Whānau-Centred Initiatives. Wellington: Te Pūni Kōkiri.

Te Hau Āwhiowhio o Ōtangarei. (2012). Photovoice final revised report, version 4. Whangarei: Te Rōpū Rangahau.

Whangarei District Council (2008). Whangarei community report. Retrieved from www.familyservices.govt.nz

\section{Corresponding author}

Terri Cassidy, Te Hau Āwhiowhio ō Otangarei Trust

Email: terri.cassidy@tehauawhiowhio.org.nz 